\section{on food labels}

material, says Steve Emmott, a spokesman for the Green group. He argues that such labels could become so widespread as to be "meaningless", so defeating the purpose of labelling.

BEUC also calls on retailers and the food industry to exert pressure on suppliers to segregate shipments. Similarly, others point out that segregation may be obtained through consumer pressure without legislation. Responding to such market pressure, major food retailers - such as the UK Iceland group - and importers have already refused all US soya bean imports. Some suppliers are beginning to offer segregated shipments.

It is still unclear how the proposed labelling requirements will relate to the rules of the World Trade Organization (WTO). Some observers suggest that they could be contested as a disguised barrier to trade. If a genetically modified product was produced by the United States but not in Europe, for example, the former could argue that labelling stigmatized its product and favoured non-modified European equivalents.

The WTO has not specifically considered genetically modified organisms, however. But, according to Behrendt, the European Parliament would resist any opposition from WTO. She argues that the legislation is non-discriminatory in that it applies to both importers and European countries. Europe has for the first time incorporated the consumer's right to be informed and to choose freely in a trade issue, she says, arguing that this "philosophy" should be respected by its trading partners.

Declan Butler

\title{
Call for reform of scientific panels
}

Paris. Franz Fischler, the European Union's agriculture commissioner, last week called for a radical reform of the way in which scientific advice is used in political decision-making within the union in the wake of the 'mad cow' crisis.

Testifying before the European Parliament's inquiry into bovine spongiform encephalopathy (BSE), Fischler suggested that management of the scientific committees to which the European Commission turns for advice might benefit from being transferred to independent organizations. This happens in the United States, where the government often asks the National Academy of Sciences and the Institute of Medicine to report on controversial topics.

Fischler said it is "essential" to provide the scientific advisory system with a reputation that commanded public respect, citing as a model the US Food and Drug Administration, an independent federal body but with law-enforcing powers. "As long as our scientific advice is questioned - as it has been in BSE - public confidence in our decisions is not going to be there," says one commission official.

Among the major questions that need to be addressed about the committees, said Fischler, is whether they are sufficiently independent from the interests of member states and lobby groups. The BSE issue showed that national perspectives are "not without importance", he admitted. The basis on which committee members are appointed needs to be re-evaluated, he said, as well as the

\section{IMAGE \\ UNAVAILABLE FOR COPYRIGHT REASONS}

Fischler: independent committees needed?

question of how to ensure that minority opinions are heard.

The European Parliament's inquiry is expected to produce proposals for a reform of the commission's system of scientific committees, which has come under fire following the BSE crisis. Critics have questioned both their scientific credentials and political impartiality.

Fischler pointed out that political decisions must be based on good science, because otherwise they could be contested at the European Court of Justice and the World Trade Organization (WTO). For example, under WTO rules, countries cannot ban imports or demand that they be labelled unless it can be shown that they fail to meet agreed standards, or if such standards do not exist - that there is firm scientific evidence of a risk (see Nature 384, 301; 1996). This made it essential for Europe to have first-class structures for analysing and evaluating risks and their political management, he said.

D. B.

\section{action to police imports of genetically altered maize}

since 1 October. It points out that many of these shipments originate from the 1996 US harvest and are therefore likely to contain genetically modified maize, given that the United States does not segregate this from non-modified maize.

Critics point out that, because border controls between member states have been virtually abolished within the single market, maize imported by any one country can circulate freely within the rest of the EU. A spokesperson from the United Kingdom's Department of the Environment said that preventing the maize from spreading within the EU would be the responsibility of the member states whose ports receive the US shipments.

The commission seems unlikely to take any immediate action against countries importing the maize, according to one official. All it has done so far is to remind member states of their obligation to respect the law, and to carry out adequate inspec- tions "to ensure compliance". The commission would need to first establish that the law is being broken, he explains, pointing out that the memorandum only says that "it is to be expected" that the imports contain genetically modified maize. The commission would then "get in touch with member states to see how they would rectify the situation", he adds.

"It is the responsibility of member states to comply," says the official, adding that the commission sees no point in taking action against the imports now, given that a decision on its authorization is expected later this month. "If member states are breaking regulations and the situation might be rectified two weeks later you don't drag them to court," he says.

On a wider level, the illegal imports have reopened the question of the commission's limited powers to police EU legislation. Under the union's founding treaties, it is the member states, and not the commission, that are responsible for ensuring that $\mathrm{EU}$ law is implemented properly. The commission only has a role of oversight, limited to taking member states to court for having violated a treaty.

But this is a long process, while the commission's ability to prove infractions have occurred is also hampered by its limited powers of inspection. "We don't police like police in your home town do," says one commission official, "we don't arrive at the scene two minutes later." He admits that "community law is violated every day".

The issue of whether the commission should be given wider powers to police legislation has become a heated one following the 'mad cow' crisis. The commission is widely considered to have lacked sufficient powers to ensure that member states, and the United Kingdom in particular, were properly implementing $E U$ rules on bovine spongiform encephalopathy (BSE) control measures (see Nature 384,$8 ; 1996$ ). $\quad$ D. B. 